\title{
The Effect of Presentation Variety of Interactive Multimedia Learning to the Learning Result
}

\author{
Muhammad Rusli \\ Stmik Stikom Bali \\ Raya Puputan 86 Denpasar, \\ Indonesia
}

\begin{abstract}
This research aims to investigate the impact of many kinds of computer-based interactive multimedia learning presentation to the learning result by controlling the student's prior knowledge. The kinds of learning presentation consist of multimedia learning with high interactivity ([animation visualization + narration] and [static visualization + clue + narration]) and multimedia learning with low interactivity ([animation visualization + narration] and [static visualization + clue + narration]). The research method used quasi experimental approach, with the kinds of multimedia learning presentation act as independent variable with 4 kinds of treatment, the student's learning result as the dependent variable, and student's prior knowledge as the covariate variable. The research was conducted in STMIK STIKOM Bali with the research subject is the students of even semester 2013/2014, and the analysis method used the Covariance Analysis. Based on the analysis results, it can be concluded that by controlling the student's prior knowledge of high interactivity multimedia learning group (built by Adobe Flash) is more effective than the low interactivity multimedia learning group (built by PowerPoint and Screencast-O-Matic). Besides that, on the high interactivity multimedia learning group, the effectiveness of the visualization content through animation+narration is equal with the content visualization through static visualization+clue+narration. This condition is also applied with the low interractivity multimedia learning.
\end{abstract}

\section{Keywords}

Multimedia learning, animation, high interactivity, low interactivity, prior knowledge, learning result.

\section{INTRODUCTION}

Delivery media, in the learning context, is one of the most important elements which affects the learning effectivity, besides the content type, learning purpose and learning method[1]. Learning through multimedia (next is called multimedia learning) which is computer-based, is one kind of a delivery media or learning media which is based on electronic whose learning is delivered through computer with the learning content (text, picture, graphic, audio, animation, etc) is stored inside CD-ROM or computer file. This multimedia learning, according to [2], has main characteristics, they are: the learning content must be relevant with the objective of learning; using learning method such as the availability of examples and practices which can help the learners to learn; and is designed so that the learners are able to learn by themselves.

Multimedia learning is called effective if it is interactive. Multimedia learning interactivity depends on the availability of learner-control facility so the learners can manage the essential information processing to avoid overloading of their cognitive process when the learning process happened
[2][3][4]. The student's control facility can be in the form of buttons e.g: stop, continue, previous, and next. By the availability of those facilities, the learners are hoped can control the knowledge transfer speed when the learning in process. The availability of these interactive buttons are different between multimedia application software. Those differences depend on the completeness and the placement of the interactive buttons and the easiness of how to operate it, especially to the navigation of the content/material that want to be learned. These differences will affect the stage of undertanding/absorbing the knowledges which are received by the learners, which later can affect the learning results which are achieved by the learners[5].

Besides that, the effectivity of the interactive multimedia learning also depends on the topic condition ( static or dinamic content type) which is presented[6][7] and the content visualization type (static or animation)[8]

This research aims to investigate the effect of many kinds of interactive multimedia learning presentation. The kinds of multimedia learning presentation acts as independent variable with 4 kinds of treatments, they are multimedia learning with high interactivity ([animation visualization + narration] and [static visualization + clue + narration]) and multimedia learning with low interactivity ([animation visualization + narration] and [static visualization + clue + narration]). The student's learning results (the ability to apply procedure of concept map in class modelling) as dependent variable. Prior knowledge (the student's understanding to object/class orientation) as the covariate variable.

This research is quantitative research with quasi experimental approach and is done in 4 parallel class sample with the same topic of Object-Oriented Modelling subject (specially approach of concept map on class modelling), one class for one treatment. It is random to determine which class gets the treatment. The experiment result data will be processed with the Covariance Analysis Statistic Method (ANCOVA).

The result of this research is hoped can give the significant differences from many kinds of interactive multimedia learning to the learning results. Then it is known that which type of multimedia learning can give more effective learning results.

\section{LITERATURE REVIEW}

\subsection{Multimedia and How Human Learns}

Multimedia consists of elements: text, picture/photo, graphic arts, sound, animation, and video elements which are manipulated digitally[9]. Meanwhile, animation according to [3], refers to a simulated motion picture which describe simulated object movements. Multimedia is delivery/ presentation content/information which are computer-based, whether by static visualization or animation visualization. The 
inside content can be in the form of words (such as narration or text on screen) and graphic/picture/ table/video.

Related with the information/content which are presented/ delivered, there are three assumptions about how human learns[10]:

(1) Human's information processing system consists of two channels, they are audio/verbal channel to process the audio input and verbal representation, and visual/pictorial channel to process visual input and pictorial,

(2) Each channel (audio and visual channel) has limited capacity,

(3) Meaningful learning needs a number of cognitive process which occupying both channels. This learning is a deep understanding on material, which covers the important aspects in the material presented, organized mentally in a cognitive structure and integrate it with the existing and relevant knowledge.

\subsection{Learning through Multimedia}

According to [2], multimedia learning (computer-based) is a type of e-learning whose instruction is delivered via computer with the learning content (text, picture, graphic, audio, video, animation, etc) saved in the CD-ROM or computer file. It has characteristics as follow:

(1) The content learnt is relevant with the learning purpose,

(2) Using learning method such as examples, practices to help the learner learns,

(3) Using media elements such as words (text) and pictures in delivering the the content and learning method,

(4) Designed for the learners to learn on their own (asynchronous learning),

(5) Building new knowledge and skill which are connected with the objective of learning and increasing the organization performance.

\subsection{Cognitive Learning Theory through Multimedia}

According to [11], cognitive process is described as a change in thought, intelligence and learner's language. This change happens because of the existence of learning process. The model of how human learns (or human mind works) is presented in Figure 1. This model is known as Cognitive Learning Theory with Multimedia [10][2]

In Figure 1, there are three important cognitive processes showed by the arrows:

(1) Words and Pictures Selection, as the first step to give attention to the words and pictures which are relevant from the presented materials in short-term memory which are connected to the senses/sensory memory,

(2) Organizing words and picture, as the second step to organize the material mentally in a coherent verbal and pictorial representative in working memory, and

(3) Integration, as the last step to integrate each verbal and pictorial representation and with the prior knowledge in long-term memory.

The sensory memory or short-term memory is a limited capacity memory system in which the information is held for about 30 seconds, except if the information is repeated or processed further; working memory is a kind of 'work desk' in which a number of information process is done; and long- term memory is a type of memory which can held many information in a long period of time relatively permanent[11].

\subsection{Information Presentation Guide in Multimedia Format}

There are seven principles of information presentation guide in multimedia format-animation[2][3], they are:

(1) multimedia principle (learners learn better from animation and narration/audio rather than by narration alone),

(2) spatial contiguity and temporal contiguity (the learners are better if the words/texts are presented closely to the animation [picture] which are relevant, and the portion connected with the narration and the animation is presented simultaniously rather than one by one),

(3) coherence (the learners learn better from the animation and narration if the words/texts, voice, and pictures which are irrelevant are deleted),

(4) modality principles (learners learn better from animation and narration rather than animation and texts in the screen),

(5) redundancy principles (learners learn better from animation and narration rather than animation, narration, and texts in the screen),

(6) segmentation/interactivity and petraining principles (learners learn better if the facility to manage the essential processing to avoid overloading on the cognitive system is available [the availability of stop, previous and next buttons], and the learners learn better if they are given orientation material session fast [relevant key concepts] connected with the material/content given before the presentation starts),

(7) personalization principle (the learners learn better from animation and narration in conversation style rather than formal style)

\subsection{The Impact of Many Kinds of Presentation on Interactive Multimedia Learning to the Learning Results}

Many kinds of presentation on the interactive multimedia learning are divided into 4 kinds of type or treatment: they are mulimedia learning with high interactivity ([animation visualization+narration] and [static visualization+clue+ narration]) and multimedia learning with low interactivity ([animation visualization + narration] and [static visualization + clue + narration $])$.

Learner-control type or the interactivity buttons built in a interactive multimedia learning can be different. The differentiation of the availability interactivity buttons and the ease/speed in operating, for the content/material navigation wanted to be learnt or the management of learners cognitive load, can affect the absorbing/understanding level of the knowledge/information received by the learners, which later on can affect to the learner's learning results[5][2]. Meanwhile, the difference of visualization type (animation vs static) on that treatment will also give significant effect on the learning results, which is that learning with animation visualization is more effective than static visualization[12][8].

Thus to match the superiority of animation visualization on this treatment, then on the treatment of static visualization is added clue or cursor which points the content being explained by the narration, thus it is hoped that the learners can be more focused (to decrease student's cognitive load) on the material being learnt. 


\section{METHODS}

\subsection{Research Variable and Experiment Design}

Thisresearch is aquantitative research with quasi experimental approach. The purpose is to test the impact of the independent variable to the dependent variable by controlling the covariate variable. The independent variable is many kinds of computer-based interactive multimedia learning with 4 kinds of treatment: multimedia learning with high interactivity ([animation visualization + narration] and [static visualization + clue + narration]) and multimedia learning

\section{Multimedia}

Presentation

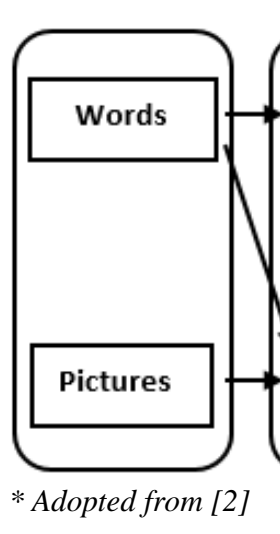

with low interactivity ([animation visualization + narration $]$ and [static visualization + clue + narration]). The dependent variable is the student's learning results (the ability to apply procedure of concept map in class modelling). Considering the student's learning results also depend on the prior knowledge (the student's understanding to object/class orientation), so the prior knowledge in this case act as the covariate variable. Thereby, the experiment design that will be implemented in this research is the factorial design with one covariate variable. This design is known as ANCOVA (Analysis of Covariance) factorial.

\section{Long-term memory}

Working memory

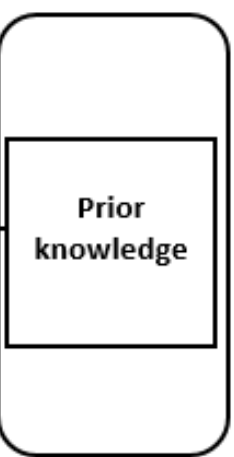

Figure 1. Cognitive theory of multimedia learning

\subsection{Research Subject}

The subject of this research is the students of STMIK STIKOM Bali which take Object-Oriented Modelling subject in even semester 2013/2014. The amount of classes which are used for this treatment are 4 classes, 1 class for 1 treatment. The determination of which class gets which treatment is done randomly. The amount of students in each class is between 30-40 students with the total students participanting in this research are 146 students as described in Table 1.

\subsection{Treatment Design and Research Variable Measurement}

There are 4 kinds of treatment in this research, they are: multimedia learning with high interactivity (A and B treatments) and multimedia learning with low interactivity (C and $\mathrm{D}$ treatments)

A and B treatments are built through Adobe Flash multimedia application software with interactivity buttons: Pulldown menu (to choose topic randomly), Stop, Continue, and Next (to the next topic). For A treatment, the content is diplayed step by step (animation) with narration. Meanwhile for B treatment the content is displayed simultaneously (static) with narration and clue/cursor which points to the content explained by the narration.

$\mathrm{C}$ and D treatment (low interactivity) is a video which is built through PowerPoint and Screencast-O-Matic application software with interactivity buttons: Stop, Run/Continue, and Control bar (to return to the previous topic or to certain topic). For C treatment, the content is displayed step by step (animation) with narration. Meanwhile for D treatment, the content is displayed simultaneously (static) with narration and clue/cursor which points to the content explained by the narration.

The topic learnt to all treatments is Concept Map and its transformation to the Class Diagram[13]. The learning is done through interactive multimedia learning which occurs in 2 meetings. The measurement of prior knowledge (student's understanding about Clas/Object orientation) is done at the end in the first meeting (after they given study about class/object orientation at the same meeting), and the measurement of learning result (the ability in applying concept map procedure in modelling Klas) is done in fourth meeting (after they have received the module of multimedia learning about concept map at meeting 2 and 3). Each meeting for all the four treatments (A,B,C and D) is done in two days in a row in the same week ( 1 day 2 treatments). The range of measurement value used to measure the prior knowledge (covariate variable) is $1-100$, and the grade of student's ability in applying procedure (dependent variable) is $1-4$. The data of the research's result is described in Table 2.

\subsection{Data Analysis Method}

Based on the experimet design, the data analysis method uses factorial ANCOVA for one factor with one covariate variable, and for the computing uses helping package of SPSS program.

There are some parametric assumptions that have to be filled (through testing) so that Factorial ANCOVA analysis can be done, which is normality of the data of dependent variable, regression homogenity and variance homogenity between cell of treatment[14][15]. 
Table 1. The student number of each treatment

\begin{tabular}{|c|c|c|c|c|}
\hline \multicolumn{3}{|c|}{ Presentation type of multimedia learning (factor) } & \multirow{2}{*}{$\begin{array}{l}\text { Student } \\
\text { number }\end{array}$} & \multirow{2}{*}{$\%$} \\
\hline Interactivity type & Visualization type & Treatment name & & \\
\hline \multirow[t]{2}{*}{ High (Adobe Flash) } & Animation+narration & A & 37 & 25.3 \\
\hline & Static + clue + narration & B & 34 & 23.3 \\
\hline \multirow{2}{*}{$\begin{array}{l}\text { Low (PowerPoint+ } \\
\text { Screencast-O-Matic) }\end{array}$} & Animation+narration & $\mathrm{C}$ & 35 & 24.0 \\
\hline & Static + clue + naration & $\mathrm{D}$ & 40 & 27.4 \\
\hline \multicolumn{3}{|l|}{ Total } & 146 & 100.0 \\
\hline
\end{tabular}

Table 2. Data of the research's result

\begin{tabular}{|l|c|c|c|c|c|c|}
\hline \multirow{2}{*}{ Treatment } & \multicolumn{4}{|c|}{$\begin{array}{c}\text { Prior knowledge } \\
\text { (covariate variable) }\end{array}$} & \multicolumn{3}{c|}{$\begin{array}{c}\text { Ability in applying procedure } \\
\text { (dependent variable) }\end{array}$} \\
\cline { 2 - 8 } & $\boldsymbol{n}$ & Mean & Standard deviation & $\boldsymbol{n}$ & Mean & Standard deviation \\
\hline$A$ & 37 & 51.2 & 12.38 & 37 & 2.56 & 0.378 \\
\hline$B$ & 34 & 58.8 & 10.31 & 34 & 2.49 & 0.370 \\
\hline$C$ & 35 & 56.4 & 13.10 & 35 & 2.33 & 0.382 \\
\hline$D$ & 40 & 54.8 & 11.8 & 40 & 2.30 & 0.414 \\
\hline
\end{tabular}

Note: $n=$ student number

Table 3. Variance analysis result of the factors effect

\begin{tabular}{|c|c|c|c|c|c|}
\hline Source & $\begin{array}{c}\text { Sum of } \\
\text { Squares }\end{array}$ & $\begin{array}{c}\text { Freedom } \\
\text { degrees }\end{array}$ & $\begin{array}{c}\text { Mean of } \\
\text { Squares }\end{array}$ & F & Sig. \\
\hline Model & $862.473^{\mathrm{a}}$ & 8 & 107.809 & 911.513 & 0.000 \\
\hline Factor $(\mathrm{F})$ & 15.954 & 4 & 3.988 & 33.722 & 0.000 \\
\hline Prior knowledge $(\mathrm{P})$ & 4.477 & 1 & 4.477 & 37.856 & 0.000 \\
\hline $\mathrm{F}^{*} \mathrm{P}$ & 0.145 & 3 & 0.048 & 0.408 & $0.748^{\text {ns }}$ \\
\hline Error & 16.322 & 138 & 0.118 & & \\
\hline Total & 878.795 & 146 & & & \\
\hline
\end{tabular}

Note: $a . R^{2}=0.981\left(\right.$ adjusted $\left.R^{2}=0.980\right) ; n s=$ not significant

\section{RESULT AND DISCUSSION}

\subsection{Parametric Assumtion Testing}

For the data result of ability of applying procedure, it is obtained Shapiro-Wilk statistic $=9.98$ and the significance is on 0.09 . This means that normality assumption of applying procedure ability is filled (with the significance rate $\alpha=0.05$ ).

Meanwhile, the analysis result of the regression homogenity test can be seen in Table 3. In the table, it can be seen that the interaction between many kinds of multimedia learning presentation factor and the prior knowledge $\left(\mathrm{F}^{*} \mathrm{P}\right)$ non significant at $\alpha=0.05$ (statistic $\mathrm{F}_{[3 ; 138]}=0.408$ and significant on $0.748>0.05$ ), then the regression homogenity assumption can be filled.

The analysis result of variant homogenity test with Levene test, it is obtained statistic $\mathrm{F}_{[3 ; 142]}=2.051$ and significant at 0.109 (bigger than $\alpha=0.05$ ). Thus the variant homogenity assumption can be filled. By the fullfilment of those assumptions then the ANCOVA analysis can be continued. The analysis result is described on Table 4.

\subsection{Research Result}

The analysis result in Table 4 shows that the effect of many kinds of multimedia learning presentation (Factor) is significant in 0.0. (smaller than $\alpha=0.05$ ). Then it can be concluded that there are significant differences of approximate learning result from those four kinds multimedia learning. Because of that, further analysis result is needed to find out which of those four treatments are different.
The result of further analysis/test is different between the pair of treatments by using the Bonferroni method as listed in Table 5. Based on this tabel, it can be concluded that the average treatment student's study group results which receive multimedia learning with high interactivity (treatment $\mathrm{A}$ and B) is higher than the study group which receive multimedia learning with low interactivity (treatment $\mathrm{C}$ and $\mathrm{D}$ ). But, for the $\mathrm{B}$ treatment, the average learning result score is not significant (same/equal) if compared to the $\mathrm{C}$ and $\mathrm{D}$ treatment.

\subsection{Discussion}

The analysis result states that the multimedia learning group in high interactivity (A and B treatment) is more effective than multimedia learning group with low interacitvity $(\mathrm{C}$ and $\mathrm{D}$ treatment), this is harmonic with the result of research by [5]. This condition can be happened because in multimedia learning with high interactivity which is built by Adobe Flash, the available interactive buttons is easier to operate it if compared to the multimedia learning with low interactivity which is built by PowerPoint and Screencast-O-Matic in managing/controlling the cognitive load of the students when the learning process in progress.

Meanwhile, the learning results from both multimedia learning with high interactivity (A vs B) can still be said as equal, considering the role of clue (animation) which points the content when the narration is delivered to manage the cognitive load of the learners, so that the learners can be more focused. This condition is also the same as both multimedia learning with the low interactivity (C and D). 
The interesting thing is that there is an average of student's learning result that receive learning with high interactivity in

B treatment which can still be said as equal/same with the student's learning result which received multimedia learning with low interactivity (for the $\mathrm{C}$ and $\mathrm{D}$ treatment). This condition can be happened because of the students/learners did not optimize in using the learner's control facility (interactivity buttons) which are available to manage the cognitive load optimally while they were learning.

Table 4. Covariance Analysis result of the factors effect

\begin{tabular}{|c|c|c|c|c|c|}
\hline Source & $\begin{array}{c}\text { Sum of } \\
\text { Squares }\end{array}$ & $\begin{array}{c}\text { Freedom } \\
\text { degrees }\end{array}$ & $\begin{array}{c}\text { Mean of } \\
\text { Squares }\end{array}$ & F & Sig. \\
\hline Model & $862.328^{\mathrm{a}}$ & 5 & 172.466 & 1476.798 & 0.000 \\
\hline Prior knowledge (P) & 4.853 & 1 & 4.853 & 41.555 & $0.000^{\mathrm{s}}$ \\
\hline Factor (F) & 20.553 & 4 & 5.138 & 43.998 & $0.000^{\mathrm{s}}$ \\
\hline Error & 16.467 & 141 & 0.117 & & \\
\hline Total & 878.795 & 146 & & & \\
\hline
\end{tabular}

Note: $a . R^{2}=0.981$ (adjusted $\left.R^{2}=0.981\right) ; s=$ significant

Table 5. The test result of treatments Bonferroni method

\begin{tabular}{|c|c|c|}
\hline Treatment & Mean & Test result* \\
\hline$A$ & 2.56 & $\mathrm{a}$ \\
\hline$B$ & 2.49 & $\mathrm{ab}$ \\
\hline$C$ & 2.33 & $\mathrm{~b}$ \\
\hline$D$ & 2.30 & $\mathrm{~b}$ \\
\hline
\end{tabular}

Note: * Significant at $\alpha=0.05$; same letter express mean of equal

\section{CONCLUSION AND SUGGESTIONS}

\subsection{Conclusion}

a. Multimedia learning with high interactivity (built with Adobe Flash) is more effective than with the multimedia learning with the low interactivity (built with PowerPoint and Screencast-O-Matic).

b. Multimedia learning with high interactivity (built with Adobe Flash), the visualization content effectiveness in animation + narration is equal or same with the static + clue + narration. This condition also applies on the multimedia with low interactivity (built with PowerPoint and Screencast-O-Matic).

\subsection{Suggestions}

a. The importance of animation in developing the interactivity multimedia learning (high/low), whether the animation which appears one by one (with narration), or animation (movement) from clue which refers to the content (static visualization) which is relevant when the narration is delivered.

b. The importance of learner control facility in form of interactivity buttons which are appropriate in building interactive multimedia learning so that self learning by the students can occur effectively.

\section{ACKNOWLEDGEMENTS}

Our gratitude goes to SEAMOLEC (Southeast Asian Ministers of Education Regional Open Learning Centre) Indonesia who has given us their supports and funds for this Research Activity in 2014. In personal, we also like to show our gratitude to the Head of STMIK STIKOM Bali and also their management for the supports and the facilities they have given us during the research

\section{REFERENCES}

[1] Clark, R.C. (2008). Developing Technical Training: A Structured Approach for Developing Classroom and Computer-Based Instructional Materials. Third Edition. San Francisco: John Wiley \& Sons, Inc.

[2] Clark, R.C. \& Mayer, R.E. (2008). E-Learning and The Science Of Instruction. Second Edition. San Francisco: In Print of Wiley.

[3] Mayer, R. E. \& Moreno, R. (2002). Animation as an Aid to Multimedia Learning. Educational Psychology Review; 14,1; 87-99.

[4] Hasler, B.S., Kersten, B. \& Sweller, J. (2007). Learner Control, Cognitive Load and Instructional Animation. Applied Cognitive Psychology Journal; 21; 713-729.

[5] McCann, B.M. (2006).The Relationship between Learning Styles, Learning Environments, and Student Success. Journal of Agricultural Education; 47,$3 ; \quad 14-23$.

[6] Guttormsen Schär, S.G. \& Zimmermann, P.G. (2007). Investigating Means to Re-duce Cognitive Load from Animations Applying Differentiated Measures of Knowledge Representations. Journal of Research on Technology in Education; 40,1; 64.

[7] Passerini, K. (2007). Performance and Behavioral Outcomes in Technology-Supported Learning: The Role of Interactive Multimedia. Journal of Educational Multimedia and Hypermedia; 16,2; 183-211.

[8] Lin, H. \& Dwyer, F. M. (2010). The Effect of Static and Animated Visualization: a Perspective of Instructional Effectiveness and efficiency. Educational Technology, Research and Development; 58; 155-174. 
[9] Vaughan, T. (2006). Multimedia: Making It Work. Yogyakarta: Andi.

[10] Mayer, R. E. \& Moreno, R. (2003). Nine Ways to Reduce Cognitive Load in Multimedia Learning. Educational Psychologist; 38,1; 43-52.

[11] Santrock, J.W. (2008). Psikologi Pendidikan. Edisi Kedua. Jakarta: Kencana.

[12] Rusli, M., Ardhana, I.W., Degeng, I.N.S \& Kamdi, W. (2014). The Effect of Presentation Strategy on Multimedia Learning-Animation vs Static Visualization - and Learning Style to Learning Result. Journal of Academic Research International; 5,$1 ; \quad 216-226$
[13] Sien, V.Y. 2009. BIT 201 Object-Oriented Modelling using UML. Lecture 1-8, lecturing items of Dual-Degree Program. STMIK-STIKOM Bali Denpasar and HELP University College Kualalumpur.

[14] Hair, J.F. Jr., Black, W.C., Babin, B.J., Anderson, R.E. \& Tatham, R.L. 2006. Multivariate Data Analysis. Sixth Edition. Upper Saddle River, New Jersey: Pearson Education, Inc.

[15] Field, A.(2012). Analysis of Covariance www.discoveringstatistics.com. Accessed date: June $28,2014$. 